\title{
Annual General Meeting of the Geological Society of India
}

\author{
12th October 2010, Bangalore, India
}

The $51^{\text {st }}$ Annual General Meeting of the Geological Society of India was held on 12th October at the National Institute of Advanced Studies (NIAS), IISc Campus, Bangalore. The meeting was attended by a large number of Fellows of the Society, guests from NIAS, Geological Survey of India (GSI), (Central Ground Water Board (CGWB), Atomic Minerals Directorate (AMD), (Indian Bureau of Mines (IBM), Department of Mines and Geology, Mysore Minerals Ltd. (MML),

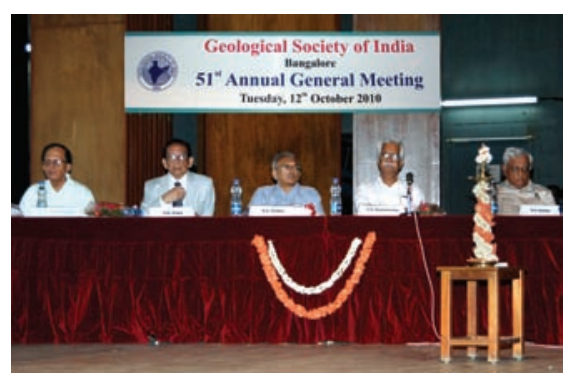

Hutti Gold Mines Ltd. (HGML), Mineral Sales Private Ltd. (MSPL) and faculty from the IISc and Bangalore and other universities.

Prof. K.S. Valdiya, INSA Golden Jubilee Research Fellow, Jawaharlal Nehru Centre for Advanced Scientific Research, Bangalore was the chief guest and Prof. V.S. Ramamurthy, former Secretary, Department of Science and Technology (DST) and presently Director, NIAS was the guest of honour.

Prof. K.S. Valdiya gave an inspiring and thought provoking lecture titled "Some questions that tease me" with beautiful illustrations and implored the Earth science community to seek evidences such as geomorphic and structural features that arise as sequel to the Indian peninsular shield under-thrusting the Himalaya as at present. He further sought evidences and effects from the signatures of Marian plume in the Indian plate such as the St. Mary Islands rhyolites, Khambat-Sabarmathi graben, Barmer graben and the Deccan lineaments, dykes, stretching of lineaments and others.

In his address Prof. Ramamurthy recalled the activities of the Indian Physicists Association and implored that the Geological Society of India should bring out more popular series booklets on various topics in the Earth System Science so as to create interest and curiosity among students and others. He further emphasized that the Society should engage school students in numerous events and activities so that they are made aware of the issues facing the planet Earth including problems of global warming, pollution, biodiversity and others.

The AGM began with a formal welcome of the Fellows by the Secretary R.H. Sawkar. He presented the Annual Report for 2009-10 and highlighted the activities of the Society. S. Jithendra Kumar, Treasurer, presented the audited statement of accounts. Fellows appreciated the efforts taken to strengthen the Society in terms of both robust activities and secured finances by the Council.

The following Society awards were presented. (1) B. Rama Rao Birth Centenary award to Prof. C. Leelanandam. (2) S. Narayanaswamy award to V. Balram and S. Ravi. (3) M.R. Srinivasa Rao award to Fareeduddin and Sisir Mondal. (4) N.N. Chatterjee award to Kalachand Sain. (5) S.S. Merh award to Pradeep Srivastava. (6) JSGI Radhakrishna prize to M. Jayananda, T. Miyazaki, R.V. Gireesh, N. Mahesha and T. Kano. (7) H.S.Pareek award to N.S. Krishnamurthy, V. Ananda Rao, Dewashish Kumar, K.K.K. Singh and Shakeel. Prof. Vishwas S. Kale received the first Prof. Vaidyanadhan award lecture. The award ceremony was followed by the release of the booklet "Story of Volcanoes" by S.K. Bhushan. Prof. Ramamurthy released the book and complimented the author.

The new Council members and office bearers for the triennium 2011-2013 were announced. President Harsh Gupta, thanked the former Council members for their

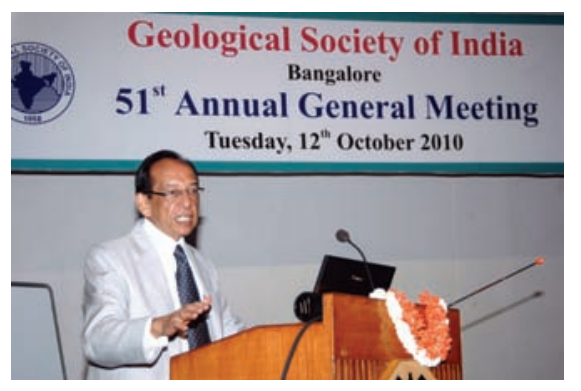

contributions and looked forward to their continued support and cooperation. He also welcomed the new Council members and office bearers and sought their vision for the coming three years. He implored that the new Council should deal with both national and global issues and proposed a National Seminar on "Earth Sciences" for 3-4 days without parallel sessions in which both paper and poster presentation would be covered. There would be a short (5 minutes) presentation for those putting up the posters and thus everyone could be heard. He further elaborated on two themes, namely where does the Society stand today in terms of national and international status and what kind of road map we need to have to reach the new objectives based on our standing. He also shared his own active area of research reservoir-induced seismicity - that is being pursued. The reservoir-induced earthquakes identified at Lake Mead in USA and other places including Koyna in India now total over 100. The reservoirs cover an area of $10 \mathrm{~km}^{2}$ or more with earthquake focal depth of about 4-6 km and an intensity of over $6 \mathrm{M}$. $\mathrm{He}$ outlined the proposed deep drilling of a $7 \mathrm{~km}$ borehole at Koyna under ICDP and the opportunities such studies provide for geoscientists. Harsh Gupta informed about the planned joint meetings of AOGS and AGU in 2012 in Singapore and the AGUEGU meeting in 2015 and appealed that we should also plan such events and should seek ways Earth science gets its proper share and representation in "planet Earth' endeavors. He also welcomed suggestions from the audience on the various issues that were delineated. In response, a number suggestions and opinions were expressed. These included the following: (a) Inviting school children to every general meeting of GSI to participate in Earth-science related awareness and sensitizing. (b) Society proactively provides guidance to groundwater harvesting schemes in Bangalore and other places. (c) Additional resource generation for the Society through advertisements in the journal and other publications. (d) Larger and intensive interactions with schools to popularize Earth science in schools. (e) More representations in the Council from Bangalore. The President informed that these aspects will be looked into by the new Council.

\section{R.H. Sawkar}

Secretary, Geological Society of India Bangalore - 560019 